Distribution of this document is unlimited.

\title{
A HEAD RESTRAINT DEVICE FOR VESTIBULAR STUDIES
}

W. Carroll Hixson, Jorma I. Niven, and Charles A. Lowery

Bureau of Medicine and Surgery

MR005.04-0021.142

NASA Order R-93,

Approved by

Ashton Graybiel, M. D.

Director of Research
Released by

Captain H. C. Hunley, MC USN Commanding Officer

20 January 1967

* This research was conducted under the sponsorship of the Office of Advanced Research and Technology, National Aeronautics and Space Administration.

NAVAL AEROSPACE MEDICAL INSTITUTE

NAVAL AEROSPACE MEDICAL CENTER

PENSACOLA, FLORIDA 32512 
THE PROBLEM

To develop a head restraint system which would provide custom-fitted restraint of individual subjects with minimal preparation time.

\section{FINDINGS}

A restraint system based on a vacuum bladder technique was constructed from standard, commercially available materials. It provides a degree of restraint comparable to that available with permanent, rigid head/torso molds individually fitted to each subject without the attendant cost in preparation time and money. 


\section{INTRODUCTION}

Of various methods used in vestibular experimentation to hold the head in some fixed orientation, the bite-bar for human subjects and tooth-clamp assembly for animal subjects have probably provided the highest degree of rigid constraint for the head. These methods are, however, unusable, or at least undesirable, in a variety of experimental situations, e.g., those in which continuous voice communications are essential, those in which severe motion sickness and the aspiration of vomitus may occur, and in linear oscillation in which device malfunction may produce impact. The bite-bar has additional disadvantages in that its efficacy is dependent upon the cooperation of the subject; inadequate pressure may permit head movement and excessive pressure may produce muscle noise or artifacts to contaminate the recording of corneo-retinal potentials or similar electrophysiological indices.

When such considerations have forbidden the use of the bite-bar method with our human subjects, we have sometimes resorted to standard U. S. Navy aviation helmets with adjustable head liners and chin straps or to individually fitted head and torso molds fabricated from plasterof-paris or polyester impregnated glass cloth. The latter technique provides excellent restraint, but its usefulness is limited by the time and cost required for the development of a separate mold for each subject; it is not at all practical for single, brief tests and, even in long or repeated applications, restricted by the number of subjects which can be conveniently handled.

It is for such reasons as these, probably, that we have received numerous requests from vestibular investigators for a brief technical description of a simple vacuum bag restraint system developed for use with our rotating devices. The basic principle involves the use of atmospheric pressure to force a flexible, airtight bladder filled with solid particles to become rigid when evacuated. The flexibility permits the bladder to be molded to the configuration of any object, such as the head, which is to be secured in one position. The rigidity is maintained as long as the vacuum is intact. The principle is not original with us, however. Indeed, it is our understanding that similar procedures have had long-time industrial application in vacuum molding, although we are unable to cite any specific instance of such use. A brief description of the materials and methods used in the application of the system in our laboratory follows.

\section{MATERIALS}

The primary elements of the vacuum bag restraint system are two rubber bladders, an inflating needle and tubing, a vacuum pump, and 6 pounds of plastic granules (see list of materials). The bladders are standard ones of the type used in boxers' striking bags and are available in any sporting goods store. Their chief advantages are availability, low cost, and adequate flexibility for molding to shape, coupled with sturdiness to resist wear and handling.

The inflating needle is likewise available in any sporting goods store. The tubing is standard, 3/8-inch, gum-rubber laboratory tubing; actually the only requirement is that it be able to resist evacuation without collapsing. The vacuum pump is of the standard diaphragm type available in most laboratories.

The plastic granules are used to create a buffer to fill the bladders to facilitate molding and to increase rigidity. They are of the type called "cooking crystals, " used by hobbyists for molding plastic objects and are readily available in most hobby supply stores. They appear to be made from a roughly formed plastic rod of about $1 / 16$-inch average diameter and are broken into irregular $1 / 20$-to-1/10-inch segments. Their small size lends itself to ready shaping of the bladder, and the irregularities in shape promote interlocking for rigidity when the bladder is evacuated. 


\section{METHOD}

In the actual preparation of the restraint assembly, each bladder is filled with 3 pounds (approximately 1-1/2 quarts) of granules through a small, circular hole made in one side. After the filling is completed, the hole is sealed with an ordinary, automobile inner-tube cold patch. The bladder is then evacuated for about 30 seconds by means of the inflating needle connected by the tubing to a vacuum pump. With the inflating needle removed, the evacuated bladder is quite rigid and usually maintains its shape well for at least twelve hours. In this respect, leakage at the bladder valve may occur if a small granule becomes lodged within the valve mechanism. This problem can usually be corrected by applying a small positive pressure to the bladder, resulting in its partial inflation.

A photograph of a bladder before and after insertion of the plastic grains is shown in Figure 1. In Figure 2 a photograph of a bladder being manually shaped to the contours of a hand is shown at the left; the resulting contours being rigidly held after evacuation are shown at the right. The specific application of the method in one device is shown in the photographs presented in Figure 3. An angle-iron support for the bladder assembly was attached to the chair as shown at the upper left. The bladder assembly is then placed between this bracket and the head as shown at the upper right. The experimenter manually compresses and forms the bladder assembly between the head and the bracket as shown at the lower left and then evacuates the bladder by means of a foot-operated switch controlling the vacuum pump. After approximately sixty seconds, the bladders are rigid and the head restraint is complete as shown at the lower right.

The vacuum bag restraint system is adaptable to fixing the orientation of the head, torso, and/or limbs of any human or animal subject. Obviously improvements could be made in materials, e.g., more flexible casing and technique, e.g., precision cutting and assembly of potterns to improve the basic fit of the bladder or to leave access openings where desired. The above description is meant only to show how commercially available materials of low cost and simple modification procedures can be used to provide a restraint system equal to or better than most of the methods currently in use.

\section{LIST OF MATERIALS}

I. Striking bag bladder, two Kantleek Model SR 1545-R (Seamless Rubber Company, New Haven, Connecticut)

2. Plastic Cooking Crystals, 6 pounds (available in hobby supply stores or from Southwest Hobbies Inc., Wichita Falls, Texas)

3. Air Pump, pressure-vacuum, motor driven, 0-30 inches of mercury (Model 1-093-5V1, Fisher Scientific Co., U. S. A.) 


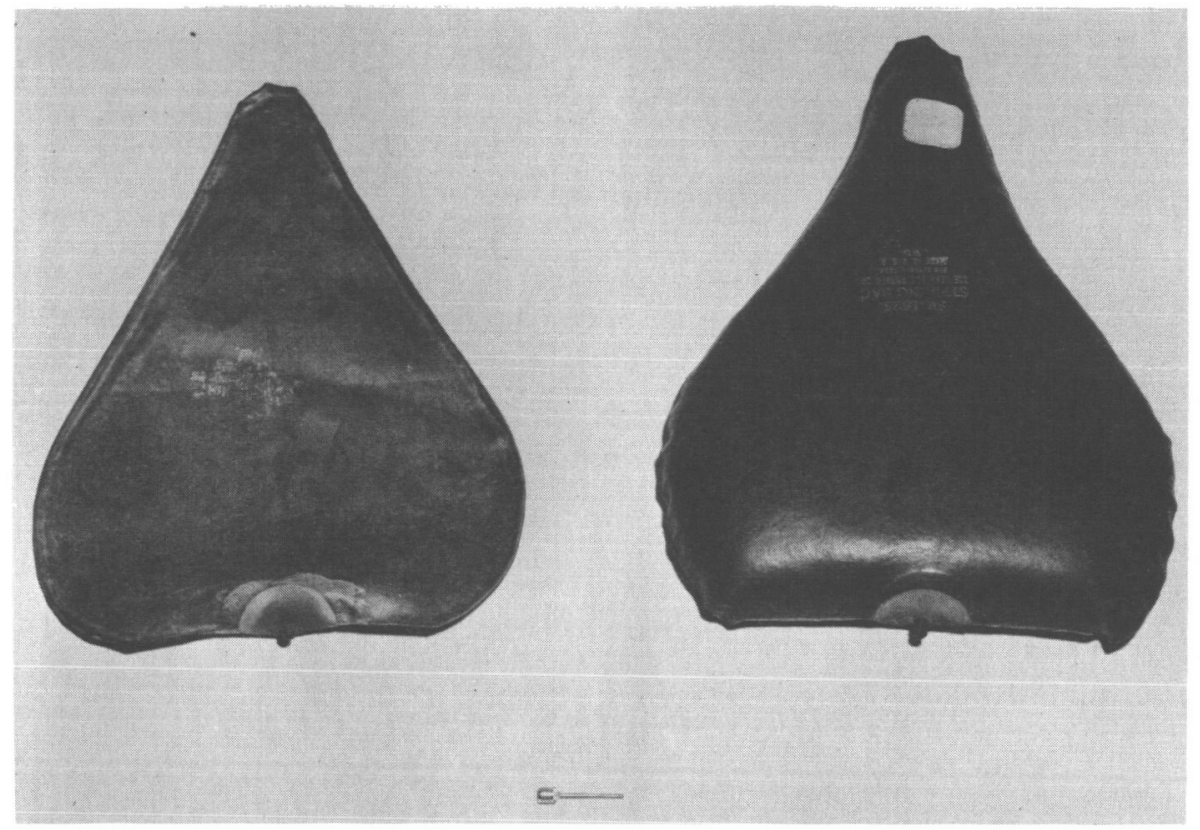

Figure 1

Striking bag bladder before and after insertion of plastic grains.
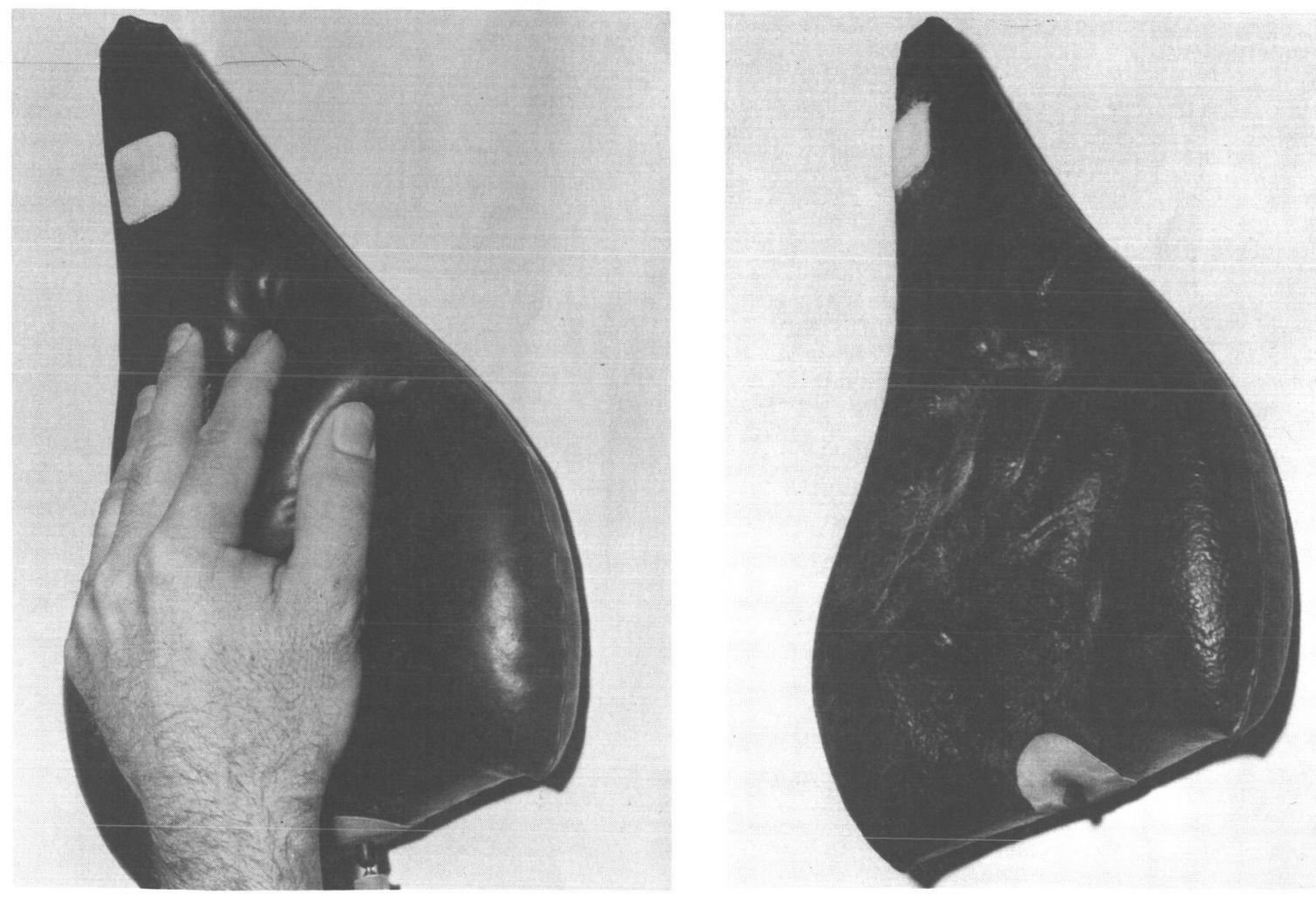

Figure 2

Plastic-filled bladder is manually shaped to the hand to illustrate its flexibility (left) and the fidelity and rigidity of the resulting contours after evacuation (right). 

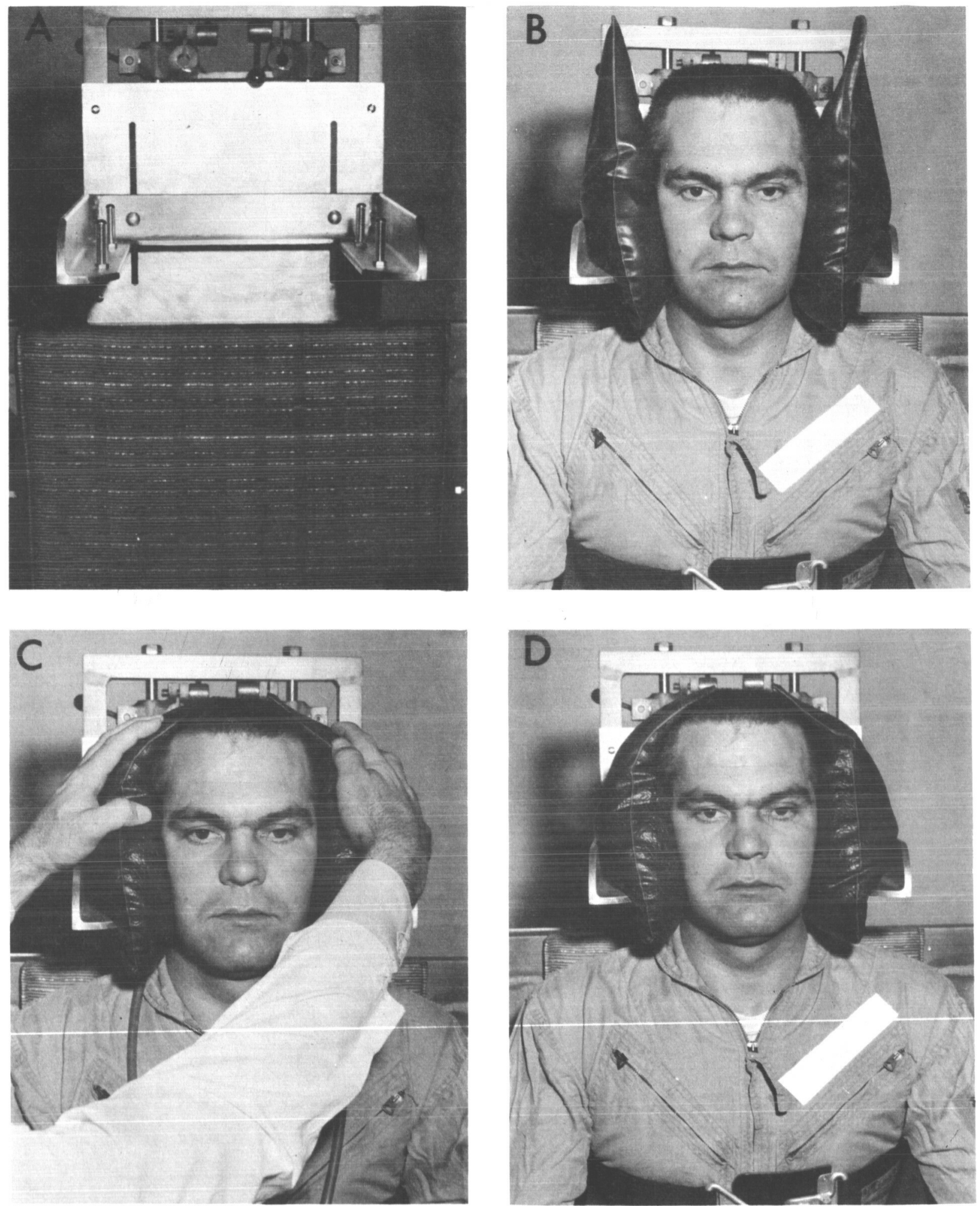

Figure 3

Typical application of the head restraint system. A simple aluminum frame (A) provides support for the bladder units placed at each side of the subject's head (B). The bladders are easily shaped to the head for a snug fit before evacuation (C) and hold their contoured shape rigidly after evacuation (D). 


\section{DOCUMENT CONTROL DATA - R\&D}

(Securtity claseification of tillo, body of abatract and indexine annotation muat bo entered when the overall roport is classified)

\begin{tabular}{l|l}
\hline 1. ORIginating ACTIVITY (Corporate author) & 2a. REPORT SECURITY CLASSIFICATION \\
Naval Aerospace Medical Institute & Unclassified \\
Naval Aerospace Medical Center & 2b. Group \\
Pensacola, Florida & $\mathrm{N} / \mathrm{A}$ \\
\hline
\end{tabular}

3. REPORT TITLE

A HEAD RESTRAINT DEVICE FOR VESTIBULAR STUDIES.

4. DESCRIPTIVE NOTES (Type of roport and inclueive datea)

5. AUTHOR(S) (Leat namo, flret namo, initial)

Hixson, W. C., Niven, Jorma I., and Lowery, Charles A.

\begin{tabular}{|c|c|c|}
\hline 6. REPO RT DATE & $\begin{array}{l}\text { 7. TOTAL NO. OF PAGES } \\
6\end{array}$ & 7b. NO. OF REFS \\
\hline $\begin{array}{l}\text { - CONTRACT OR GRANT NO. NASA R-93 } \\
\text { b. PROJECT NO. }\end{array}$ & \multicolumn{2}{|c|}{$\begin{array}{l}\text { 9. ORIGINATOR'S REPORT NUMBER(S) } \\
\text { NAMI-992 }\end{array}$} \\
\hline 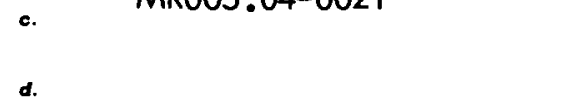 & \multicolumn{2}{|c|}{ 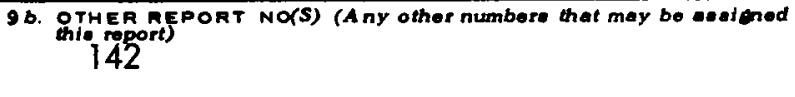 } \\
\hline
\end{tabular}

10. AVAILAEILITY/LIMITATION NOTICES

Distribution of this document is unlimited.

\begin{tabular}{|l|l|}
\hline 11. SUPPLEMENTARY NOTES & 12. SPONSORING MILITARY ACTIVITY \\
\hline
\end{tabular}

13. ABSTRACT

A restraint system based on a vacuum bladder technique was constructed from standard, commercially available materials. It provides a degree of restraint comparable to that available with permanent, rigid head/torso molds individually fitted to each subject without the attendant costs in preparation time and money. 


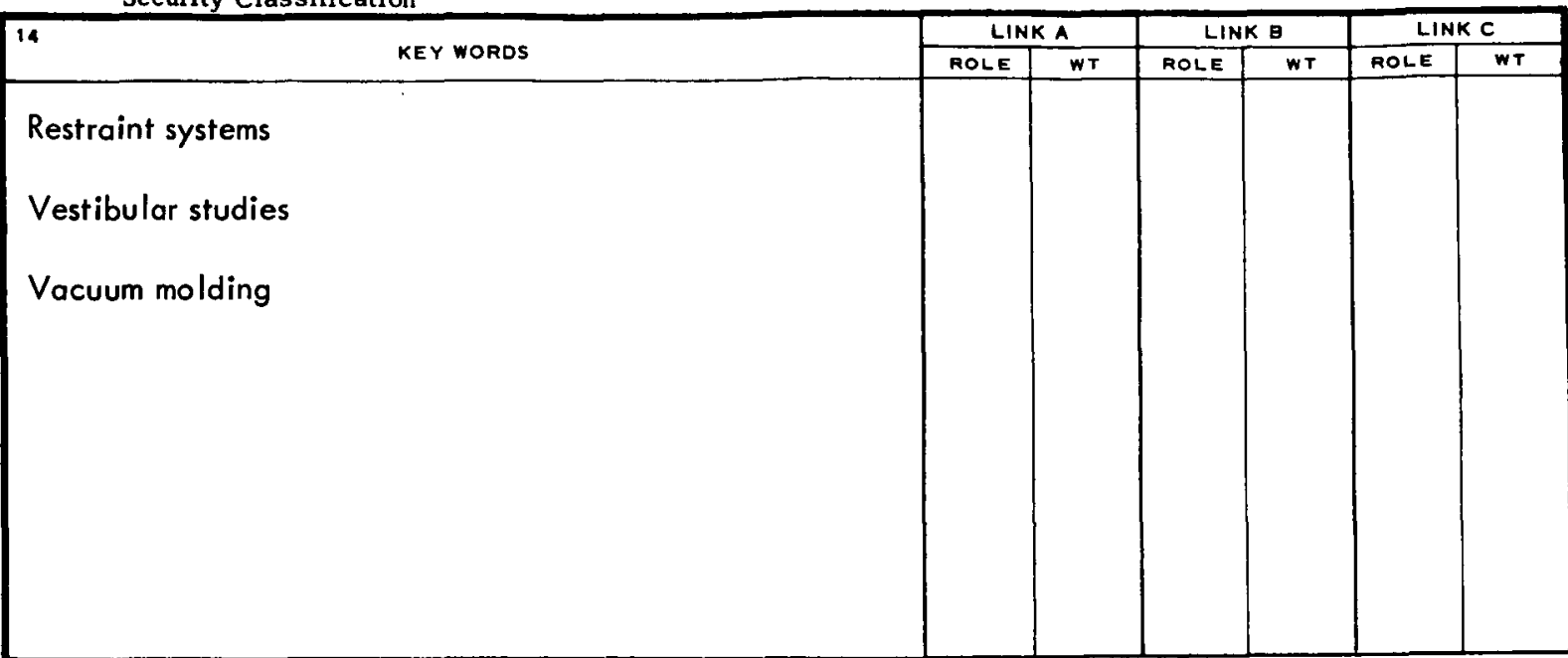

\section{INSTRUCTIONS}

1. ORIGINATING ACTIVITY: Enter the name and address of the contractor, subcontractor, grantee, Department of Defense activity or other organization (corporate author) issuing the report.

2a. REPORT SECURT Y CLASSIFICATION: Enter the overall security classification of the report. Indicate whether "Restricted Data" Is included Marking is to be in accord ance with appropriate security regulations.

2b. GROUP: Automatic downgrading is specified in DoD Directive 5200.10 and Armed Forces Industrial Manual. Enter the group number. Also, when applicable, show that optional markings have been us ed for Group 3 and Group 4 as authorized.

3. REPORT TITLE: Enter the complete report title in all capital letters. Titles in all cases should be unclassified.

If a meaningful title cannot be selected without classifica-

tion, show title classification in all capitals in parenthesis immediately following the title.

4. DESCRIPTIVE NOTES: If appropriate, enter the type of report, e.g., interim, progress, summary, annual, or final. Give the inclusive dates when a specific reporting period is covered.

5. AUTHOR(S): Enter the name(s) of author(s) as shown on or in the report. Enter last name, first name, middle initial. If military, show rank and branch of service. The name of the principal author is an ahsolute minimum requirement.

6. REPORT DATE: Enter the date of the report as day, month, year; or month, year. If more than one date appears on the report, use date of publication.

7a. TOTAL NUMBER OF PAGES: The total page count should follow normal pagination procedures, $i$.e., enter the number of pages containing information.

7b. NUMBER OF REFERENCES. Enter the total number of references cited in the report.

8a. CONTRACT OR GRANT NUMBER: If appropriate, enter the applicable number of the contract or grant under which the report was written

8b, \&c, 8d. PROJECT NUMBER: Enter the appropriate military department identification, such as project number, subproject number, system numbers, task number, etc.

9. ORIGINATOR'S REPORT NUMBER(S): Enter the official report number by which the document will be identified and controlled by the originating activity. This number must be unique to this report.

9b. OTHER REPORT NUMBER(S): If the report has been assigned any other report numbers (either by the originator or by the sponsor), also enter this number(s).

10. AVALLABILITY/LIMITATION NOTICES: Enter any limitations on further dissemination of the report, other than those imposed by security classification, using standard statements such as:

(1) "Qualified requesters may obtain copies of this report from DDC."

(2) "Foreign announcement and dissemination of this report by DDC is not authorized."

(3) "U. S. Government agencies may obtain copies of this report directly from DDC. Other qualified DDC users shall request through

(4) "U. S. military agencies may obtain copies of this report directly from DDC. Other qualified users shall request through

(5) "All distribution of this report is controlled Qualified DDC users shall request through ."

If the report has been furnished to the Office of Technical Services, Department of Commerce, for sale to the public, indicate this fact and enter the price, if known.

11. SUPPLEMENTARY NOTES: Use for additional explanatory notes.

12. SPONSORING MILITARY ACTIVITY: Ent er the name of the departmental project office or laboratory sponsoring (paying for) the research and development. Include address.

13. ABSTRACT: Enter an abstract giving a brief and factual summary of the document indicative of the report, even though it may also appear elsewhere in the body of the technical report. If additional space is required, a continuation sheet shall be attached.

It is highly desirable that the abstract of classified reports be unclassified. Each paragraph of the abstract shall end with an indication of the military security classification of the information in the paragraph, represented as $(T S),(S),(C)$, or $(U)$

There is no limitation on the length of the abstract. However, the suggested length is from 150 to 225 words.

14. KEY WORDS: Key words are technically meaningful terms or short phrases that characterize a report and may be used as index entries for calaloging the report. Key words must be selected so that no security classification is required. Identifiers, such as equipment model designation, trade name, military project code name, geographic location, may be used as key words but will be followed by an indication of technical context. The assignment of links, roles, and weights is optional. 